\title{
Destined to be defaulted: Local government insolvency and bailout in post-transition Hungary ${ }^{\diamond}$
}

\author{
Izabella Barati-Stec $\mathrm{a}^{*}$ \\ a Central European University, Hungary \& Budapest Business School, Hungary \\ *corresponding author's email address: izabella.barati@gmail.com
}

\author{
H I G H L I G H T S: \\ 1. The paper shows how Hungarian decentralization has unfolded since the early 1990s. \\ 2. Summarizes and gives a critical overview of the current legislative changes. \\ 3. Unveils the systemic risks associated with municipal borrowing in post transition economies. \\ 4. Highlights how inadequate planning can lead to municipal financial distress.
}

\section{Article History}

Received: 02-11-2014

Accepted: $11-12-2014$

Available online: 13-12-2014

Keywords:

Local public finance;

Local insolvency;

Municipal bail-out;

Sub-national debt.

JEL Classification:

H12; H71; H74; H77.

allows use, distribution and reproduction in any medium, provided the original work is properly cited.

\subsection{Introduction}

In Hungary, as in many other Central and Eastern European (CEE) countries, 1990 was a time of euphoria. With the end of centralized planning, local communities obtained the right to form local self-governments and to make decisions about the community on their own. Although expenditures have been decentralized, revenues have remained fairly centralized, even two decades after the transition to democracy.

In Hungary, the result of this failure to provide adequate fiscal autonomy has been tension and asymmetries among Hungarian municipalities. In order to address these concerns, Hungary has introduced a series of structural and financial reforms to its administrative system since 1990. After 2005, further government reform plans focused on the need for some recentralization instead of broadening fiscal freedom at the local level. Current reforms include creating a new administrative level between the level of the counties and municipalities, moving from a passive form of control over borrowing to an authorization process, and centralizing the provision of services such as education and health care. 
The second section of this paper describes the Hungarian public administration system and gives an overview of the main laws passed since 1990 concerning municipalities and their effects on municipal finance, describes local borrowing and its regulation in Hungary while in the third section, I evaluate the current changes taking place, and, in the conclusions I make a few suggestions for possible reforms.

\subsection{Designing a new system: the Hungarian public administration}

In Hungary, three main waves of legislation were passed after 1990. The first created the framework for a decentralized public administration system. The second preceded accession to the European Union and ensured enhanced public accountability. In 2010, Hungary's public administration entered a third phase with the recentralization of certain tasks and finances. ${ }^{1}$

\subsection{The levels of administration}

In 1990, the Hungarian Parliament guaranteed the independence of municipalities through several laws, among which the most important were the Constitution and Act LXV (1990) on Local Governments. The old Constitution in force before January 2012 listed the rights of local governments and also regulated the organizations and mechanism for the protection of these rights. Act LXV (1990) created a new form of public administration, laid down its operational rules, and regulated the scope and duties of public administration at each level of government.

Hungarian municipalities - which have an average population of $2,600^{2}$ - are smaller than municipalities in most OECD countries. More than half of Hungary's municipalities have a population below 1,000. Although we can find other fragmented systems in countries such as France or Switzerland with its average municipal size of 1800 and 2800 respectively, Hungarian municipalities have greater responsibilities than municipalities of the same size in other OECD countries. This situation raises the question of economies of scale. Many small settlements, although obliged by Act XCV (1990) to provide services such as collecting and treating waste water and garbage, are not able to fulfill such responsibilities or carry out the necessary investments on their own. In older democracies, ${ }^{3}$ forced amalgamations have sometimes been used ${ }^{4}$ to solve this problem.

In Hungary, the strongest impediment to forced amalgamation is the negative memory of the council system before 1990,5 when forced cooperation among municipalities deprived small villages of basic services. As a result of this history, voluntary municipal associations were favored by the state subsidy system in the early 1990s. The creation of notary districts ${ }^{6}$ and municipal associations ${ }^{7}$ was another way to counter high administration and service delivery costs.

There are two main differences between notary districts and municipal associations. First, notary districts are parts of the state administration system and serve administrative tasks, while associations are specifically created to deliver public services. Second, creating notary districts is obligatory under the aforementioned conditions, whereas creating associations is voluntary. ${ }^{8}$

The national administration also created "micro-regions" and although the geographical boundaries of these in many cases corresponded with those of the associations, they were not the same. The associations had real service functions, while micro-regions were created only for statistical reasons, that is, after accession to the EU, Hungary needed a territorial system that corresponded to the EU's regional policies - a level of organization that could be the recipient of EU regional grants. ${ }^{9}$

\footnotetext{
1. For more on this question, see Krugman (2011) and Scheppele (2011).

2. Without Budapest, the capital city, the average population is 2560. If Budapest is included, this number is 3,100 (based on KSH (Central Statistical Office) data, 2013)

3. Such as Denmark, Sweden, the Netherlands, Germany, or Canada.

4. As pointed out by Swianiewicz, (2010), amalgamations, of course, also have negative effects, such as distancing citizens from decision-making bodies, the overuse of some services, and decreases in service quality.

5. Hungary's public administration system before 1990 could be characterized by a vertical integrity and hierarchy of settlements, in which bigger municipalities had greater rights and more political power, and upper tiers of the hierarchy were responsible for lower tiers.

${ }^{6} \mathrm{~A}$ "notary district" in Hungary is a group of municipalities that employs only one person as notary for fulfilling administrative tasks in all of them, thus saving on administrative expenses. These municipalities also offer their public services together. Neighboring municipalities with fewer than 1,000 inhabitants (the number in 2012 rose to 2,000) are required to create notary districts for the purpose of fulfilling their administrative responsibilities. The higher the number of inhabitants within a notary district, the higher the level of central government subsidies. The number of notary districts has risen slowly; there were about 500 of them in 2000 and there are about 700 today.

7 Municipal associations have also been created between the local and the county level. The central government's tool for encouraging municipal associations was not to give them direct subsidies, but rather to threaten them with lower subsidies if they did not form an association. If the number of recipients of a particular service did not reach a level set by the government, ${ }^{7}$ the municipality - or association - was not eligible for a subsidy. Municipalities could be members of more than one association for different purposes. According to Hungarian legislation, municipal associations were financed through their members and entitled to state subsidies. They cannot levy taxes, making it difficult for them to issue bonds or borrow from a bank for investments. If a development is financed by an association and a bank loan is needed - which is typically the case - the bank would need to make contracts with each municipality. Given that some associations have more than 30 members, transaction costs were very high.

${ }^{8}$ Creating municipal associations also meant that Hungary could have moved from type I multi level governance to type II, according to the MLG classification by Hooghe and Marks (2001).

${ }^{9}$ Interestingly, this level used to be a formal government tier under the communist era, but its tasks were taken away in 1990.
} 
The next level of government is the county. Counties are responsible for tasks that must be carried out at a higher level than that of municipalities, although a municipality can take such tasks over if it has the necessary fiscal and management capacity. An example for this could be the maintenance of high schools or art schools. The potential hazard of this practice is that the county is often left with the most expensive tasks to carry out. The revenue-raising capacity of the county is limited, as under Act XCV (1990); a county government cannot levy taxes or collect fees. Having the most expensive tasks to carry out and not being able to raise their own revenues has meant that counties needed to borrow to maintain the level of their services.

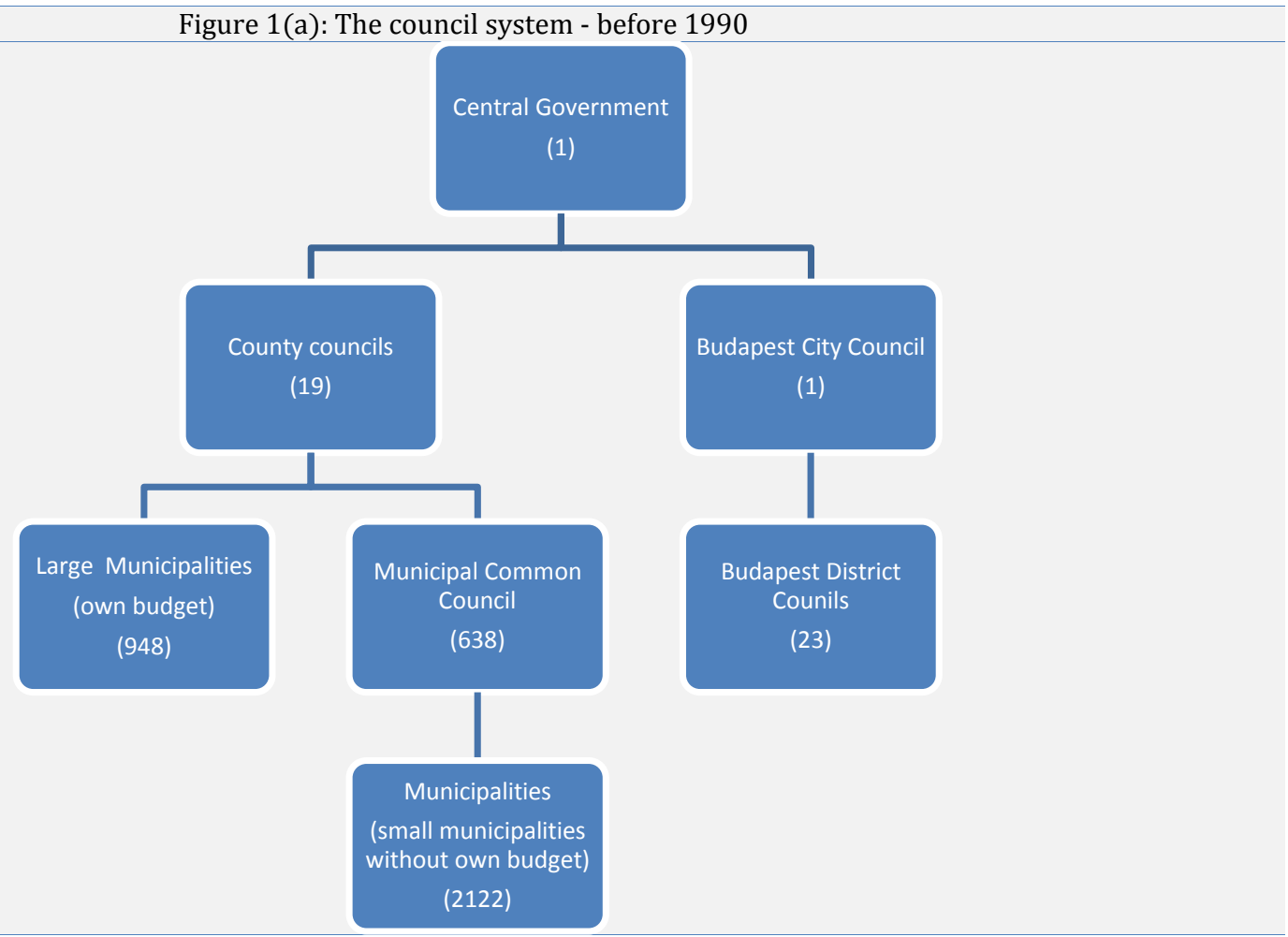

Hungary's territory is divided into seven regions. The circumstances of their creation were similar to those of the micro-regions; that is, the creation of regions was a requirement of the European Union for statistical reasons. The regional territorial development offices were delegated to this level and these offices were also responsible for the approval of EU grants. Figure 1 gives an overview of the Hungarian Territorial System (a) before the transition, (b) between 1990 and 2013 and (c) the most recent situation.

Figure 1(b): The Hungarian territorial system between 1990 and 2013

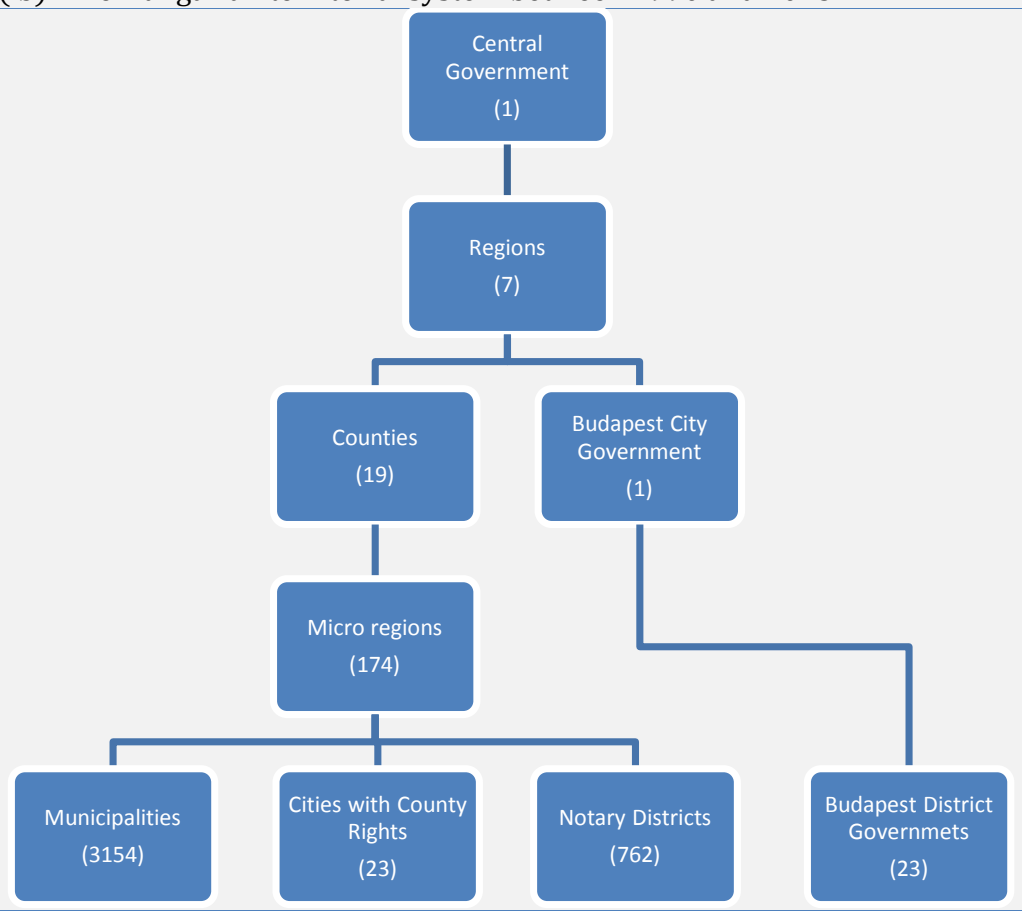


Figure 1(c): The current Hungarian territorial system as a result of the 2013 reform

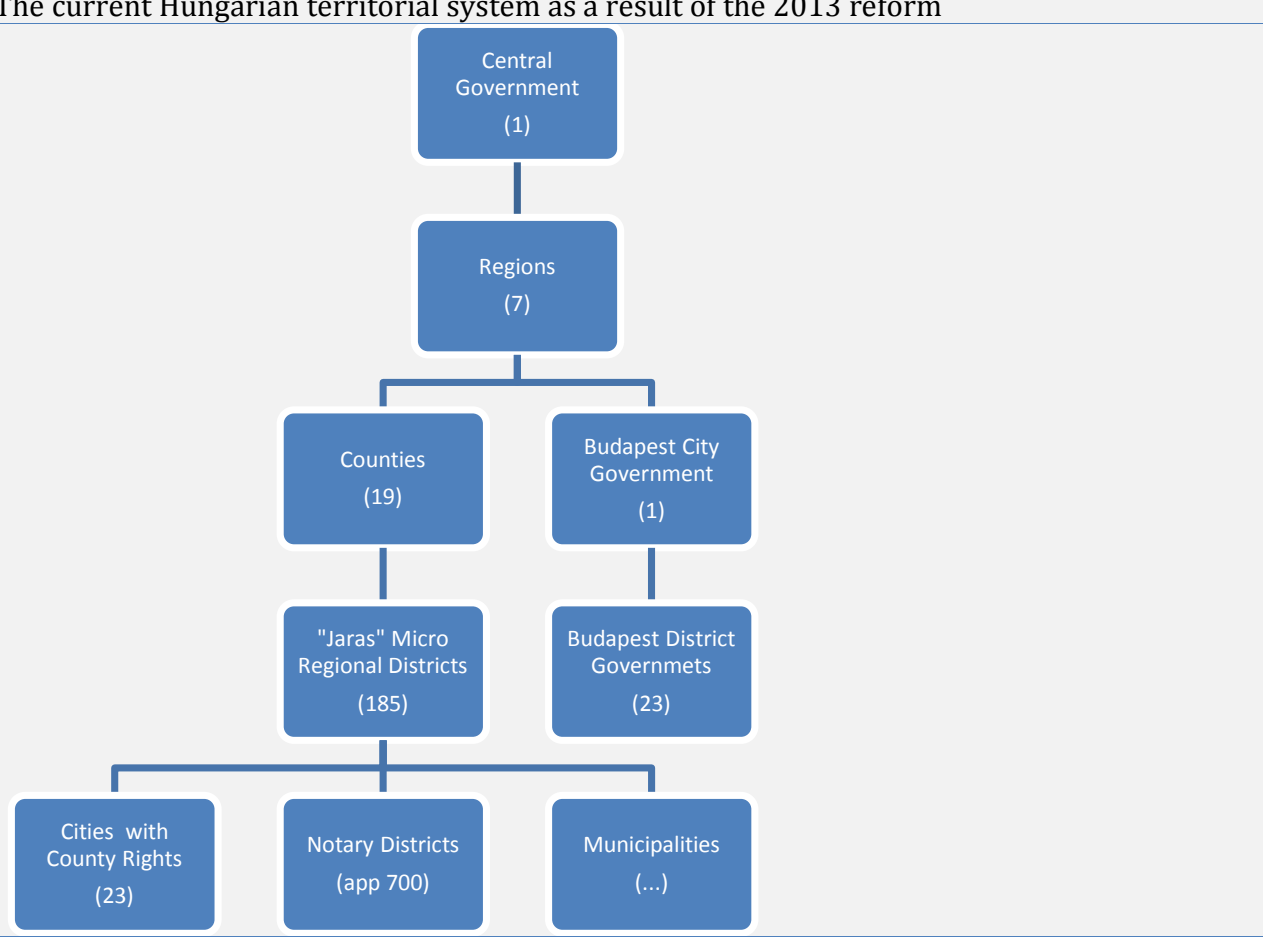

Transfer of property rights in 1990 - A source of asymmetry:

After 1990, municipalities acquired the assets necessary to fulfill services at their level, such as water treatment plants or garbage dumps, as well as buildings for administrative offices and schools. Many of these assets were sold in the early 1990s, as municipalities found it difficult to maintain them. The revenue from privatization was spent partly on other capital investments and partly on operating expenses. Of course, the value of these buildings and land depended on the economic development of the area, so more fortunate municipalities received assets that were much more valuable than those of other municipalities. The result was a gap among their fiscal capacities.

The value of buildings and land a municipality possesses is important for creating public-private partnerships (PPPs). Because those who engage in PPPs and provide foreign direct investments prefer bigger cities and richer areas for their investments (where the level of the available infrastructure is higher), and because the business turnover tax is the most important local tax, richer municipalities tend to fare better than smaller, less wealthy ones. According to the study by Barati-Stec and Hogye (2012) ${ }^{10}$ some municipalities have been able to finance large investments such as water and sewage infrastructure out of their operating budgets, because they had large business turnover tax revenues; other municipalities that cannot collect this tax and use it as collateral for loans or spend tax revenues directly on investments must rely on state funds. This situation has further exacerbated the differences in fiscal capacity among municipalities.

\footnotetext{
10 The Department of Public Policy at Corvinus University has conducted several surveys among Hungarian municipalities. In this paper, the author refers to two surveys, one done in 2010, the other in 2011. The research in 2010 examined the 100 largest Hungarian municipalities' investment techniques and economic and political expectations. The method used was in-depth interviews with mayors, other political leaders, and managers of the municipalities. In 2011, public policy students at Corvinus University interviewed representatives of 19 municipalities (they approached 24 municipalities, but only 19 responded) in the Budapest region. The purpose of the research was to identify municipal budgeting techniques and economic expectations and to assess municipal views about the current economic situation and legislative process in Central Hungary. These settlements are typically better off than the rest of the country, are most likely to have larger tax base and had substantial investments even during the economic downturn.
} 


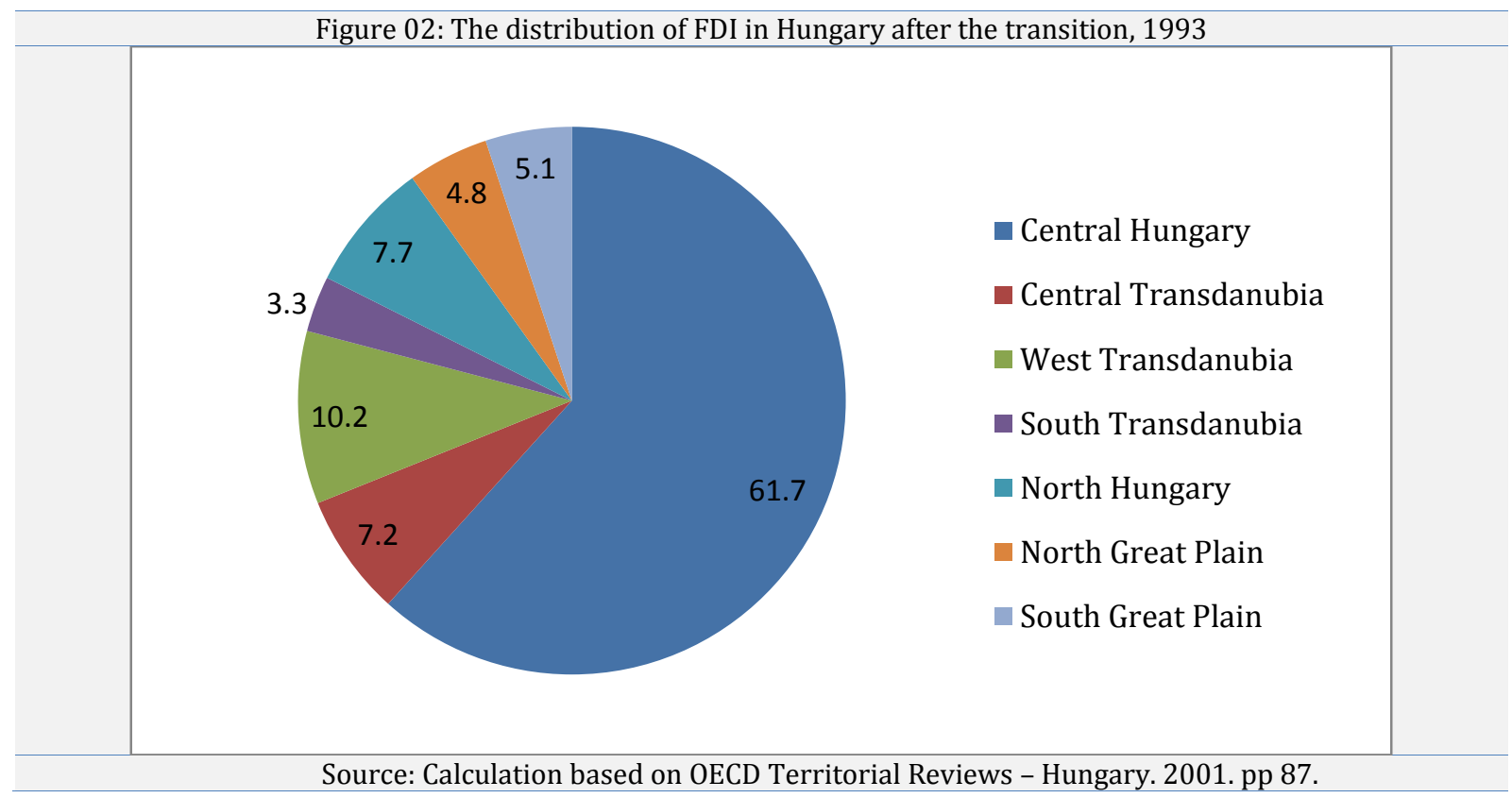

In Hungary, municipalities can sell property (land or buildings) only under two circumstances. First, the property cannot be directly related to fulfilling obligatory local services. Second, the income cannot cover operating costs. Regulations also prohibit municipalities from using strategically important land and buildings as collateral for loans. ${ }^{11}$

Municipalities, however, have found loopholes in these regulations, since it is possible to reclassify municipal property. ${ }^{12}$ Consequently, municipalities with operating deficits often reclassify their properties. Another way to get around the regulation is to sell assets through off-budget institutions. This can happen only with the approval of the municipality. Practices like this also raise the question of corruption. ${ }^{13}$

\subsection{The composition of Hungarian municipal revenues}

Although Hungarian municipalities have financial resources - such as local taxes and fees on services - that are independent from centralized decision making, own-source revenues represent less than one-third of the local budget. According to the local tax law - Act C on local taxes that came into force in 1991 and has been amended by the Parliament almost every year since - , local governments have discretion over levying local taxes and over the tax rate. Act $C$ describes the tax types (the objects and payers of the tax) and the maximum level of tax a municipality can levy. Local decrees on taxation must stipulate (i) who pays the tax, (ii) the basis of the tax, (iii) any exemptions, (iv) the rate of the tax, and (v) the conditions of beginning and ending tax obligations.

As is most EU countries, Hungarian municipalities are obliged to separate their current and capital budgets. A general rule is that current expenses should not be financed from investment income, but in practice this does sometimes happen as municipalities may sell assets through off -budget institutions ${ }^{14}$ or, as described later, issue general-purpose bonds and use the income for financing operation ${ }^{15}$. State subsidies and shared taxes may not be used for repaying loans. With creative accounting, however, municipalities can evade these rules. In the same year, they may prove to creditors that they are in a sufficiently good financial situation to borrow for new investments while proving to the central government that they need emergency or "vis major" grants. ${ }^{16,17}$

\footnotetext{
11. Using buildings as collateral was a highly criticized practice of the Hungarian municipal credit market. On the one hand, the value of the asset often surpassed the amount of the loan; on the other hand, using an asset to finance a project to which it is not otherwise related is not economically efficient. The market for buildings and land can also be very volatile.

12. For example, buildings belonging to a local school cannot be sold, but if the school is moved into another building, the property becomes saleable.

13. In October 2011, Sandor Pinter, Hungary's Minister of Interior Affairs, denied the existence of corruption in Hungary. One month later, the Ministry of Public Affairs and Justice announced that the level of corruption threatens the operation of public administration.

14. Off-budget institutions are institutions of the municipality that have a separate budget from that of the municipality. In fact, the budget of these institutions does not appear in the municipal budget, therefore it is very difficult to trace and publicly control their revenue flows and transactions.

${ }^{15}$. . The assets sold through off- budget institutions are school and office buildings, land, etc. that were originally qualified as non-sellable assets - directly related to the obligatory tasks of the government - , but after reclassification - e.g. moving the institution into another, usually less valuable building became sellable assets - not directly related to the core functions of the government. At this point the municipality authorizes the off-budget institution with its management, which very often means it will be sold. This can happen if the municipality decides to "rationalize" the service of education and moves two schools into one building. Than one of the original school buildings will go under the management of the off-budget institution -- to be sold over a matter of some time. Municipalities could also become indebted through their off-budget institutions as guarantors of their debts. The amount borrowed by the off budget institutions were only considered as part of the total of municipal loans if they defaulted.

16. In Hungary, the Latin term "vis major" is the equivalent of "Force Majeur" in English Common Law. A vis major grant in Hungary is given to a municipality that has become indebted because of reasons outside its control (such as a flood).
} 


\subsection{Local taxes in the context of municipal borrowing}

Under current legislation in Hungary, the main local taxes are the business turnover tax, the communal tax, the property tax, and the tax on tourism. The shared taxes are the personal income tax (PIT) and the vehicle tax.

The business turnover tax:

The main local tax is the business turnover tax and it constitutes about $10 \%$ of total municipal income. The business turnover tax is levied on the net income of the company, after the costs of services and materials (that is, non-labour inputs) are deducted. The business turnover tax has been widely criticized in Hungary for increasing differences among the different sub-national units and because it is very sensitive to economic cycles: in 2008 local governments relying largely on this kind of tax almost went bankrupt when their biggest taxpayers had to close down. ${ }^{18}$ Its volatility - as shown in figure 3 - makes the business turnover tax an unreliable source for example backing investment loans or financing services at the local level. Another criticized feature of the tax relates to its calculation, that is, if this tax covers services (benefit principle, see Ebel and Taliercio (2010)) than not profitable companies should also have pay it ${ }^{19}$.
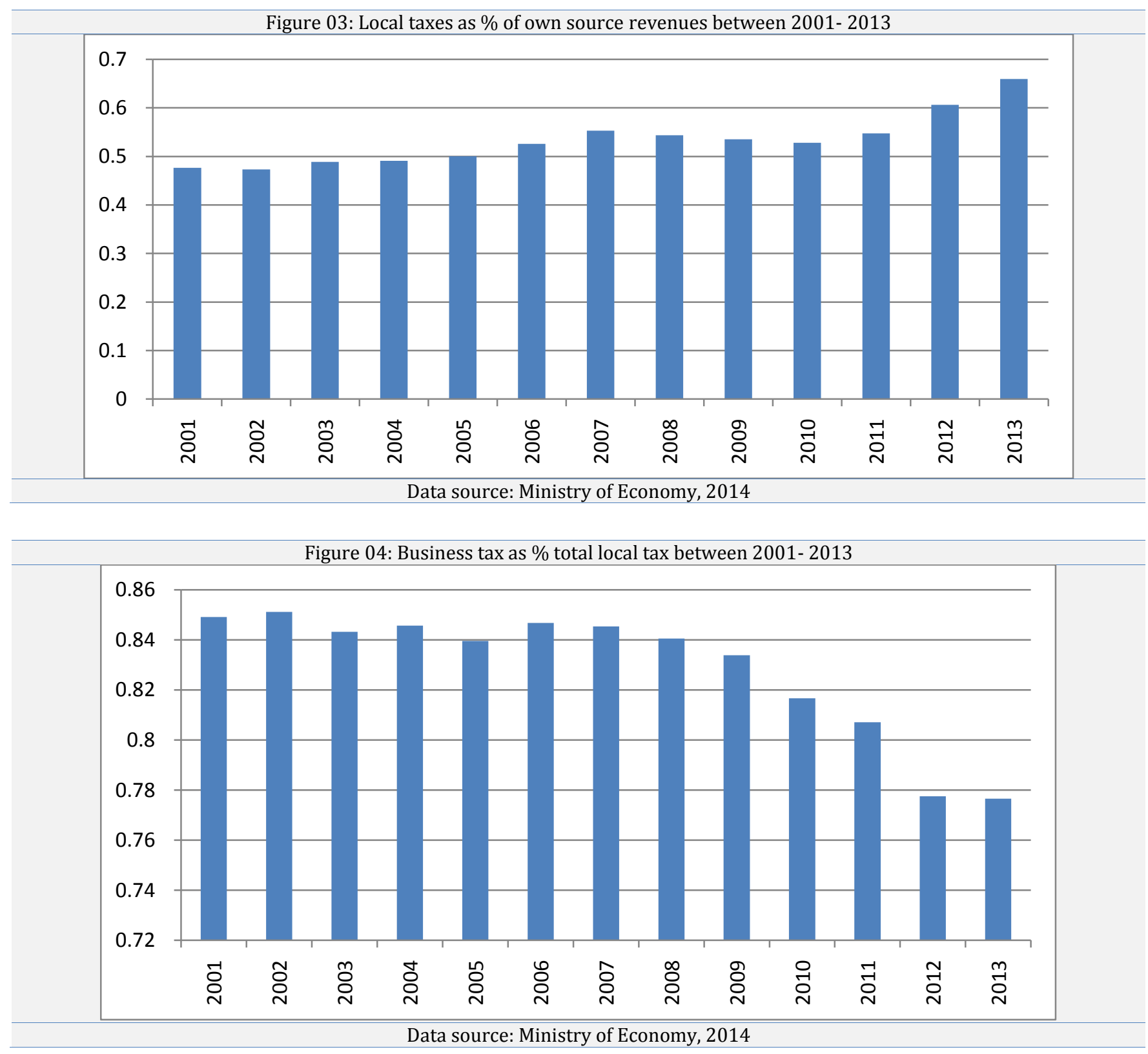

${ }^{17}$ Large cities, like Pecs, with very high debt was also eligible for a 'vis major' grant 1.5 billion HUF in 2012 . Hódmezővásárhely, a city with a debt of 20 billion Huf also got more than 1,5 billion state grant under different purposes the month before the 2012 interim local elections. Among the smaller municipalities one example is Harkany, a small settlement famous for its thermal bath. When the baths was to be sold by its private owner, the municipality offered more for the it than private bidders did. This transaction - the village had to operate the baths - caused insolvency. Harkany was the biggest winner of vis major grants in 2012 in its county.

18. When the Russian market collapsed, some Hungarian municipalities with taxpayer companies producing mainly for the Russian market almost went bankrupt.

19. For more about the benefit principle and evaluating local taxes see Ebel and Taliercio (2005). For other possible classification of taxes see Boadway and Kitchen (1999), Slack (2009) and Szalai and Tassonyi (2004). 
The maximum rate is 2 percent, but the municipality can set a lower rate or can choose not to levy this tax at all. Since 2010 it has been collected through the central tax authority (Nemzeti Adó- és Vámhivatal, or NAV), but the recipients are local governments. Even with this low rate many settlements are reluctant to levying at the maximum ${ }^{20}$, but as the example of Budapest - where the number of tax payers did not decrease compared to its neighbors with a lower tax rate - shows, being afraid of tax competition should not influence decision making, companies value the available infrastructure more than the low rate of tax in the given settlement ${ }^{21}$ (benefits principle).

The communal tax:

The Hungarian Communal Tax is a head tax, levied on a per-capita base. It is a typical form of lump-sum tax. Although 60 percent of municipalities have introduced it, its revenue generating capacity and economic impact are not significant. Communal tax income represents only 2 percent of municipal budgets.

\section{Property tax:}

The rate of the tax is set by the municipality. Property tax in Hungary in most cases is levied based on the size of, and the geographic area where the property is. The law on local taxes says that municipalities can levy property tax based on market value, at a maximum 3\% rate, in reality, many municipalities choose not to levy it value based ${ }^{22},{ }^{23}$.

\section{Tax on tourism:}

This tax is typical in tourist areas ${ }^{24}$. The interesting feature of this tax is that the central government, when calculating normative transfers, ${ }^{25}$ takes into account the tax capacity of the municipality, including the tax on tourism in the touristic areas. If this tax is levied and collected, then the amount of the grant is raised with its amount. This provision encourages municipalities to levy this tax to the maximum level. The amount of tax can be calculated based on the number of guest nights (300 huf per night) or based on the rate paid, in which case it is $4 \%$.

Personal income tax:

Personal income tax (PIT) is a centrally collected tax that is partly redistributed to the local level. In 1990, 100 percent of the PIT was redistributed to the municipality from which the revenues originated, but in 2006, only 8 percent went to the originating municipality, and another 20 to 25 percent to other municipalities, while the remaining app. 65-70 percent was kept by the state. In 2011 the remaining 8 percent share of PIT that had stayed at its origin also got turned over to the central government. Employees have a choice of filing their returns themselves or authorizing their employers to file for them.

Vehicle tax:

The vehicle tax was originally levied based on the weight of the vehicle, but in 2007 its calculation was changed. Now it is levied based on the horsepower (or kilowatts) of the vehicle and calculated on a sliding scale, meaning that the first deductions are possible after the car reaches four years of age. The starting amount is 340 Hungarian Forints per kilowatt (at the time of writing the paper about \$1.70). The income from the vehicle tax constitutes about $2 \%$ of local budgets. Hungarian municipalities cannot use the income from the PIT and the vehicle tax for repaying loans, because they are shared taxes.

Transfers from the central government:

Central grants represent another revenue source at the local level. The aim of transfers is to create a balance between the revenues and expenditures of different regions, because municipal responsibilities must be fulfilled everywhere. The main question is whether it is possible to design a grants system that balances expenditure needs and the allocation of revenues. Hungary gives grants to municipalities for capital investments and also for operating purposes; the latter are known as normative grants. Normative grants could be conditional or unconditional. In 2014 they represent approximately $20 \%$ of local income. Unconditional grants ${ }^{26}$ are rare in Hungary, although this

\footnotetext{
20 This fear was the reason why Budapest postponed introducing the highest rate until 1996.

${ }^{21}$ Here I would like to refer to the benefits principle, as this tax is paid by non residents indirectly for benefitting from local infrastruture services.

22 If a property is sold, the new owner has to pay a duty that is based on the sale price. The sale price and the duty are then recorded in the land registrar of the municipality. Municipalities sometimes use this data for assessing the value of property. In general we can say that property value assessment in Hungary is

${ }^{23}$ The property tax is best administered by the local level, since it means identifying each parcel of land, as well as tracking land improvements and changes in ownership - records that are kept at the local level. This tax produces the most stable income for the municipality, and has a positive impact on improving creditworthiness. Nevertheless, if property values fall as they did in the United States and some European Union countries such as Spain and Ireland after 2008, the property tax could also prove to be an unstable basis. As we can read in Paulais (2009), in the USA, where property tax provides the largest source of local revenues some municipalities them reported a more than $45 \%$ decline compared to previous year.

24 The owner of the business is a "tax collector agency" and the tax is for covering the indirect services the municipality offers to tourists. See again the benefits principle Ebel and Taliercio (2005).

25 . Normative grants are the contributions of the state to maintain public services. For calculating the sum of the normative grant, an indicator and a perunit cost element are used. Indicators usually reflect the "load" measurement, e.g., the number of children in school. The cost elements are the same for every municipality, even though the real costs can vary.

26. The main forms of grants are unconditional (general) grants, conditional non-matching grants, and matching grants. With unconditional (general) grants, the central government supports the municipality without any conditions on the use of the grant. Conditional non-matching grants are earmarked grants; the municipality can use it only for specific purposes. This type of transfer is the most appropriate method for local governments to meet national
} 
type of transfer would give the most autonomy to municipalities and is most consistent with Article 9 of the European Charter on Local Self-Government. ${ }^{27}{ }^{28}$

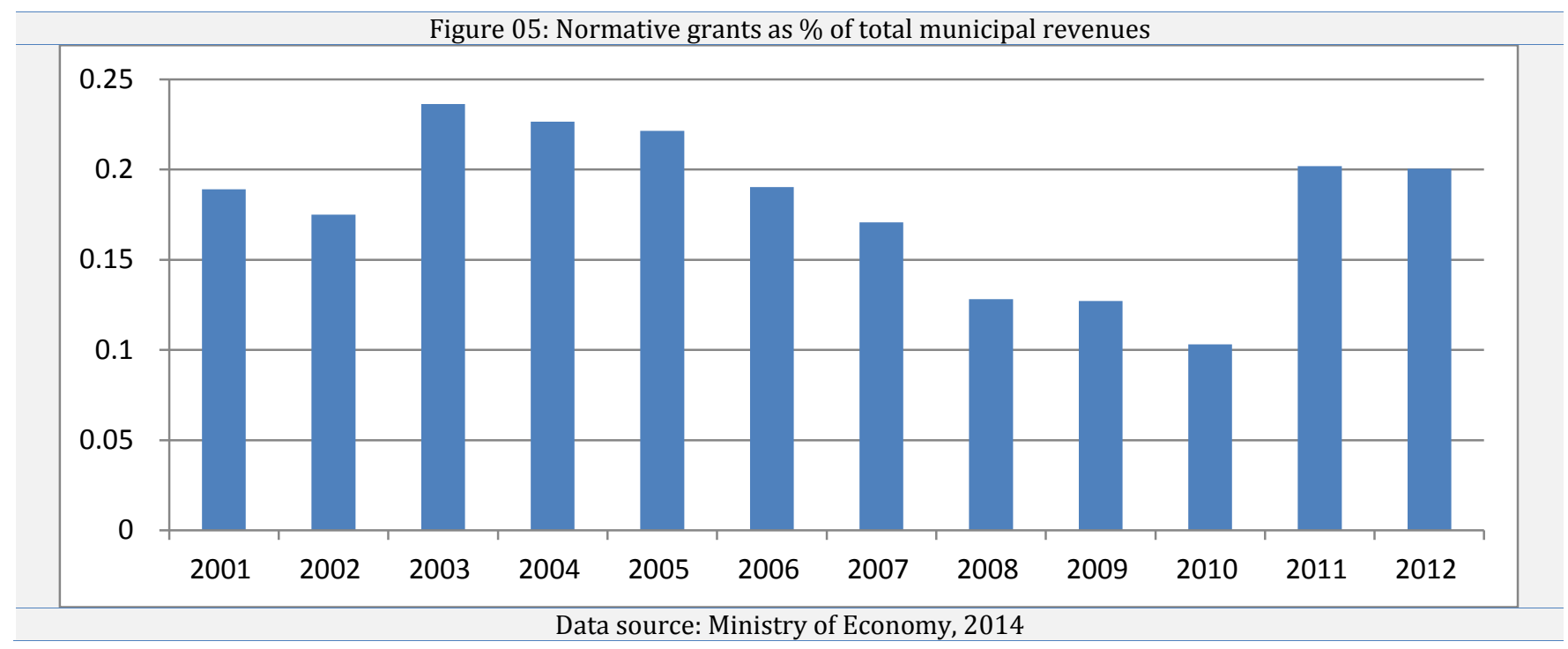

Although centrally allocated resources in Hungary cannot be used for loan repayment, the assessment of the creditworthiness of a municipality is affected by the perception of transfer dependence. The available amount of central transfers in Hungary has never been predictable, since the central level can cut transfers without agreement from the local level. Moreover, the factors affecting the changes in grant amounts are not set out in law. Thus municipalities are largely defenseless against central decisions over transfers. Cuts in subsidies can cause difficulties in debt repayment and municipalities that cannot raise local income must decide between fulfilling a service and repaying the debt. For many municipalities, the solution - which represents a serious threat to the state budget - is to keep repaying the debt from the local budget and to apply for emergency grants for providing local services. The availability of emergency grants creates the illusion that the municipality is able to maintain its services and finance its debt at the same time.

Table 01 summarizes the number of municipalities that asked for emergency grants in various years between 1993 and 2011. In 2011, more than one-third of Hungarian municipalities needed this type of aid and almost two third in 2013.

\begin{tabular}{lcc}
\hline \multicolumn{3}{l}{ Table 01: The number of Hungarian municipalities receiving emergency grants ${ }^{29}$} \\
\hline Year & Emergency grants & \% of all municipalities \\
\hline 1993 & 165 & 5 \\
1998 & 888 & 27 \\
2002 & 1,279 & 40 \\
2007 & 1,050 & 33 \\
2011 & 1,182 & 37 \\
2012 & 1,743 & 54 \\
2013 & 1,894 & 61 \\
\hline \multicolumn{2}{l}{ Sources: www.kormany.hu, www.allamkincstar.hu, Ministry of Economy } \\
\hline
\end{tabular}

\subsection{Municipal borrowing in Hungary}

Loan practices and moral hazard:

In Hungary, municipalities borrow directly from domestic banks and also issue bonds. In the case of bond issues, however, the buyer will also be the bank itself and since there is no secondary market for these bonds either, these "issues" are really bank loans. Loan-financed investments are subject to central approval as part of the subsidy system and lenders often presume that the government has also approved the loan. By implication, the central

standards, regardless of their revenue capacity. Matching grants require subnational governments to contribute to a subsidized program. A typical form of matching grants is a partial cost reimbursement, which can be a very effective tool for the central government as it can direct municipal spending by lowering the local "price" of services.

27. Notwithstanding the provisions of the Charter, even EU grants come earmarked.

${ }^{28}$. The purpose of unconditional grants could be to develop rural areas, create jobs, and reduce differences in regional development. Unfortunately, these grants rarely meet their goals. Their effect is usually smaller than the central government expects due to substitution - that is, the revenues that the municipality previously used for that purpose may be spent on another program and the municipality may reduce its own expenditures in the area of the grant. This is called the "fungibility problem" of grants. For a discussion on the fungibility of transfers, see Boadway and Shah (2009), 309-312.

${ }^{29}$ In 2012 the name of the grant changed, but its purpose remained the same. 
government's approval was perceived as taking responsibility and offering guarantees for the loan. The guarantee made loan financing cheaper through reduced interest rates, enabling municipalities to access more borrowing than they could otherwise undertake. ${ }^{30}$

If a municipality pursues an unsafe fiscal policy resulting in the need for a bailout - and the central government is ready to take this action, the burden it imposes on every other municipality in the country is small but the overgrazing municipality's gain is measurable. For this reason, more and more municipalities will try to raise more loans than what they are able to repay as observed by Gillette (2011)). If over-borrowing occurs on a large scale, the provision of public services can be jeopardized. If more than one municipality raises larger loans than they are able to repay, the financial system is burdened as a whole and the creditworthiness of the country can be adversely affected as described by Liu and Webb (2011).

The 1995 Budget Act in Hungary introduced the first limits on municipal borrowing. The relevant paragraph was abolished by the Constitutional Court, however, for violation of procedures, but the main ideas on setting constraints on local borrowing were incorporated into the Act on Local Governments in 1996. According to these new rules, municipal borrowing could not exceed 70 percent of the municipality's own adjusted current income, which meant that a municipality could not incur loans that exceeded 70 percent of the difference between its shortterm income and short-term obligations in a given year. ${ }^{31}$ Act XXV (1996) on Municipal Bankruptcy was unique among the countries of the region. It aimed to introduce hard budget constraints on local governments by asserting that the state is not responsible for local debt. This legislation was passed at a time when many municipalities, facing hard budget constraints, had introduced new local taxes to finance their obligations.

Figure 06 shows the sudden increase in the number of municipalities imposing some form of local tax in 1996 in response to the new regulation. Almost all Hungarian municipalities introduced local taxes by 2000.

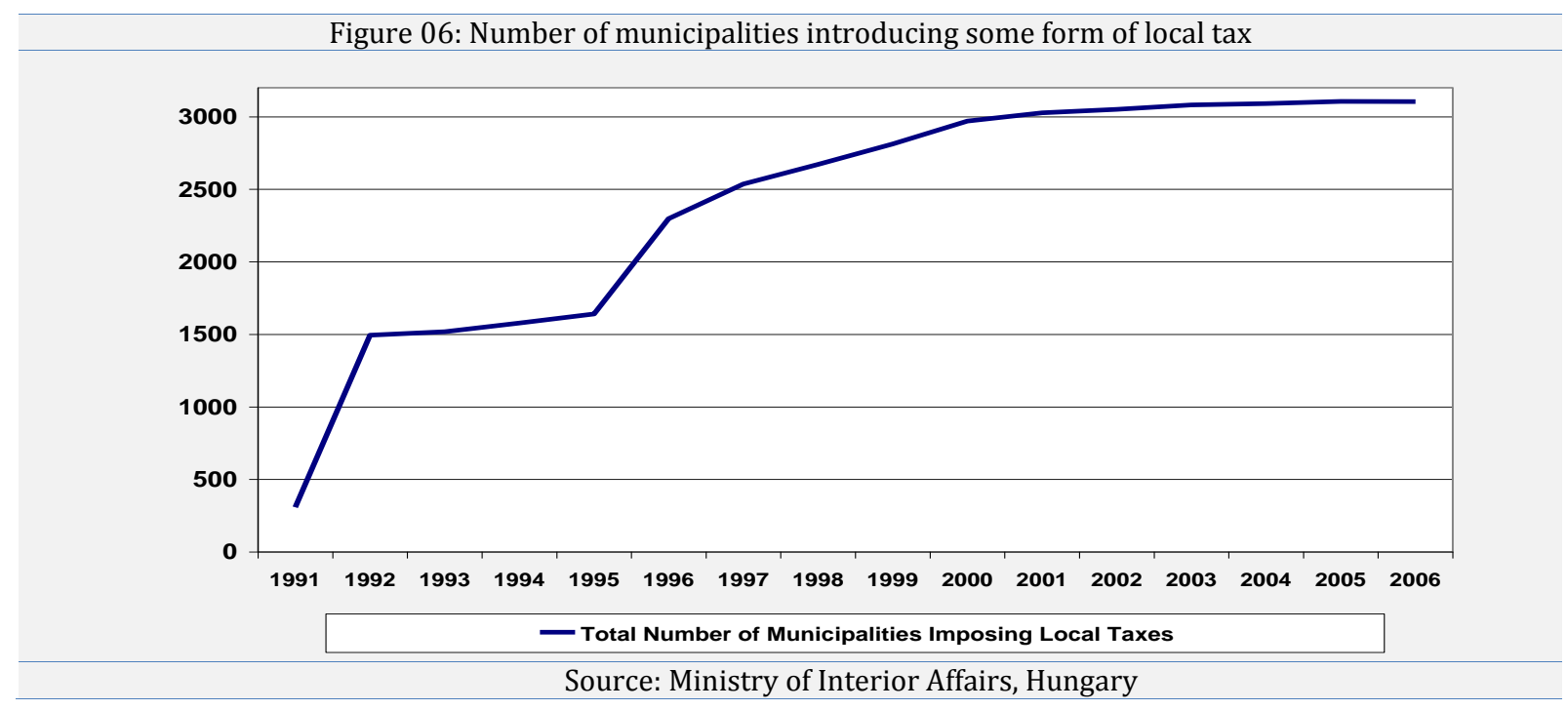

At the same time that many municipalities were introducing new local taxes, some sought out private partners for infrastructure investments. Figure 07 indicates the increasing number of contracts between the two sectors (contracting out) and the amounts transferred by the municipalities to the private sector.

\footnotetext{
${ }^{30}$. If a municipality pursues an unsafe fiscal policy resulting in the need for a bailout, the burden it imposes on every other municipality in the country is small, but the overgrazing municipality's gain is measurable. For this reason, more and more municipalities will try to raise more loans than what they are able to repay as described by Gillette (2011).

31. The enforcement of this law was questionable. According to Gal (2012), some municipalities went beyond their borrowing limits and the Ministry of Internal Affairs only found out about these cases much later.
} 


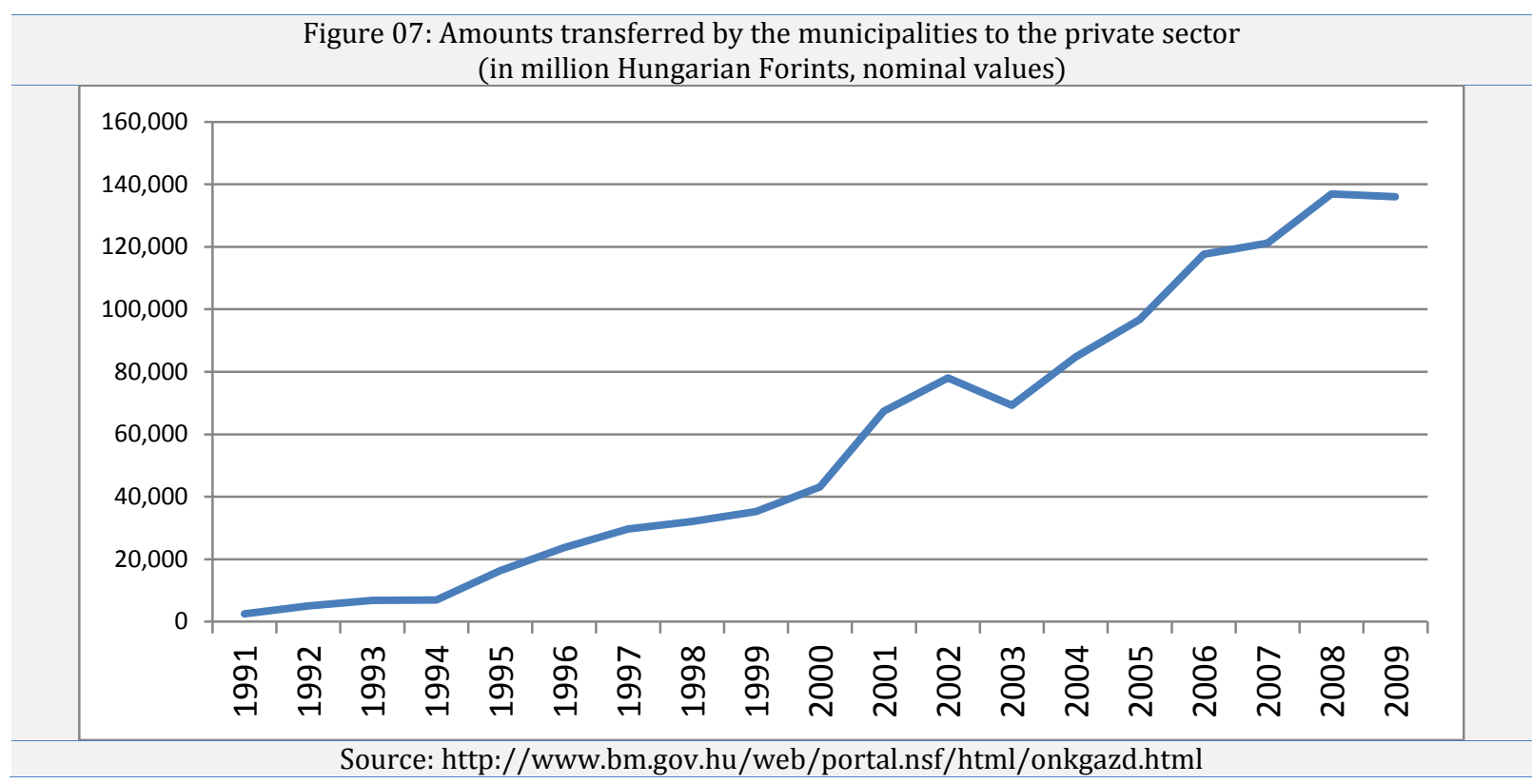

The Municipal Bankruptcy Act also laid down the procedures to be followed if a municipality falls 60 days behind its obligations. A key element of the process is the appointment by the court of a trustee who prepares an emergency budget, makes decisions on what services will be carried out in the future (usually only the obligatory services), and prepares a plan about how to restructure the debt and reorganize municipal services. In reality, lenders assumed that the state would sooner or later give additional "emergency" grants to cover municipal deficits and as the result of a legal case, they likely would have had to write off a portion of their debt. Therefore, a safer strategy for lenders was to wait and almost all cases of municipal bankruptcy have been initiated by the municipality itself. ${ }^{32}$

Foreign currency loans:

Municipalities can also borrow in foreign currencies. As the chart below shows in 2009-2012 almost 70\% of local debt - bonds and loans - was denominated in Swiss Franc and Euros (Figure 8), making debt service payments very expensive due to the very high value of the Franc (see Figure 9).

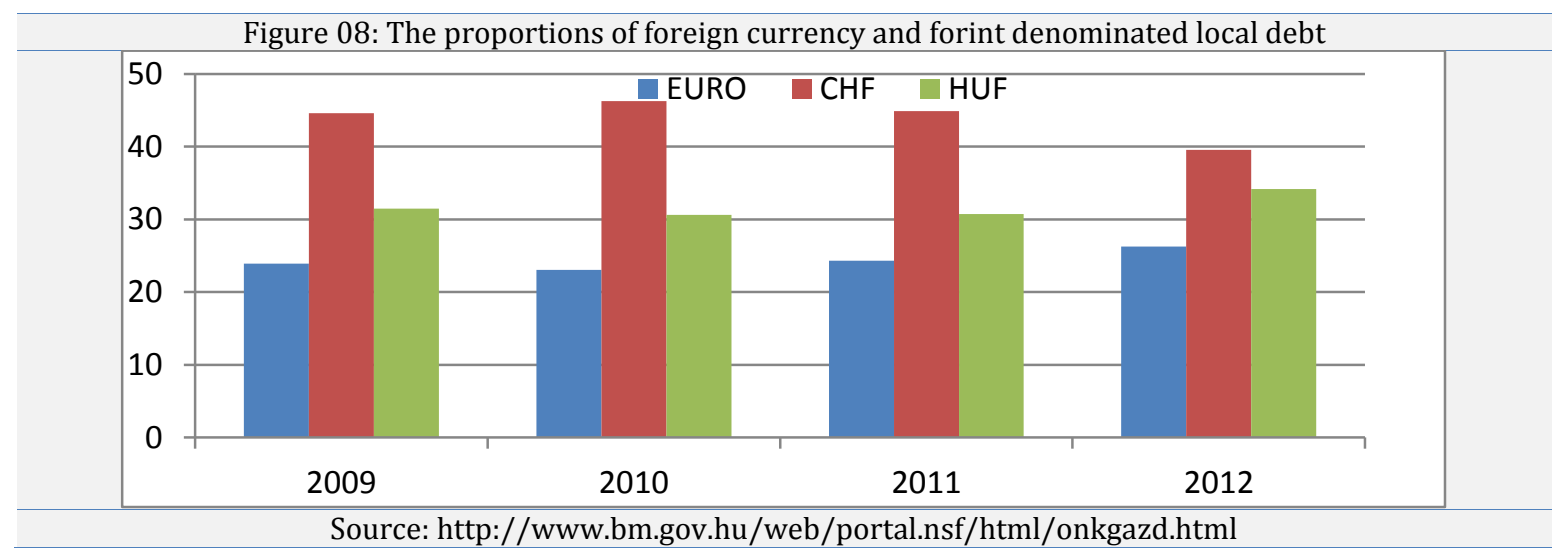

In 2010, municipal indebtedness amounted to US\$6 billion, 5 percent of the country's GDP, partly due to changes in the exchange rate. By itself 5 percent does not seem to be very high in comparison with other European countries. The average local public debt in the $27 \mathrm{EU}$ countries was 5.6 percent in 2008 . Higher numbers applied to Italy and France (both about 8 percent) or Spain (10 percent). What makes the Hungarian data alarming is the rate of change. The amount of Hungarian public debt rose more than 20 percent from 2007 to 2008, while the EU average for the same period is only 4 percent (Chatrie 2009). From 2009 to 2010, \$4 billion local public debt grew to $\$ 6$ billion - another 50 percent change.

\footnotetext{
32 As a result, only a few municipalities have undergone this process, since most come to an agreement with their creditors before the court makes a decision, although many more have threatened strategic bankruptcies. About half the cases that have made it to the court have ended in rescheduled repayments; in other cases, the lender banks have had to write off the loans so the municipality could start with a "clean slate."
} 
Figure 09: The change of foreign currency denominated loans and bonds of the Hungarian municipal sector (Amount in billion HUF)

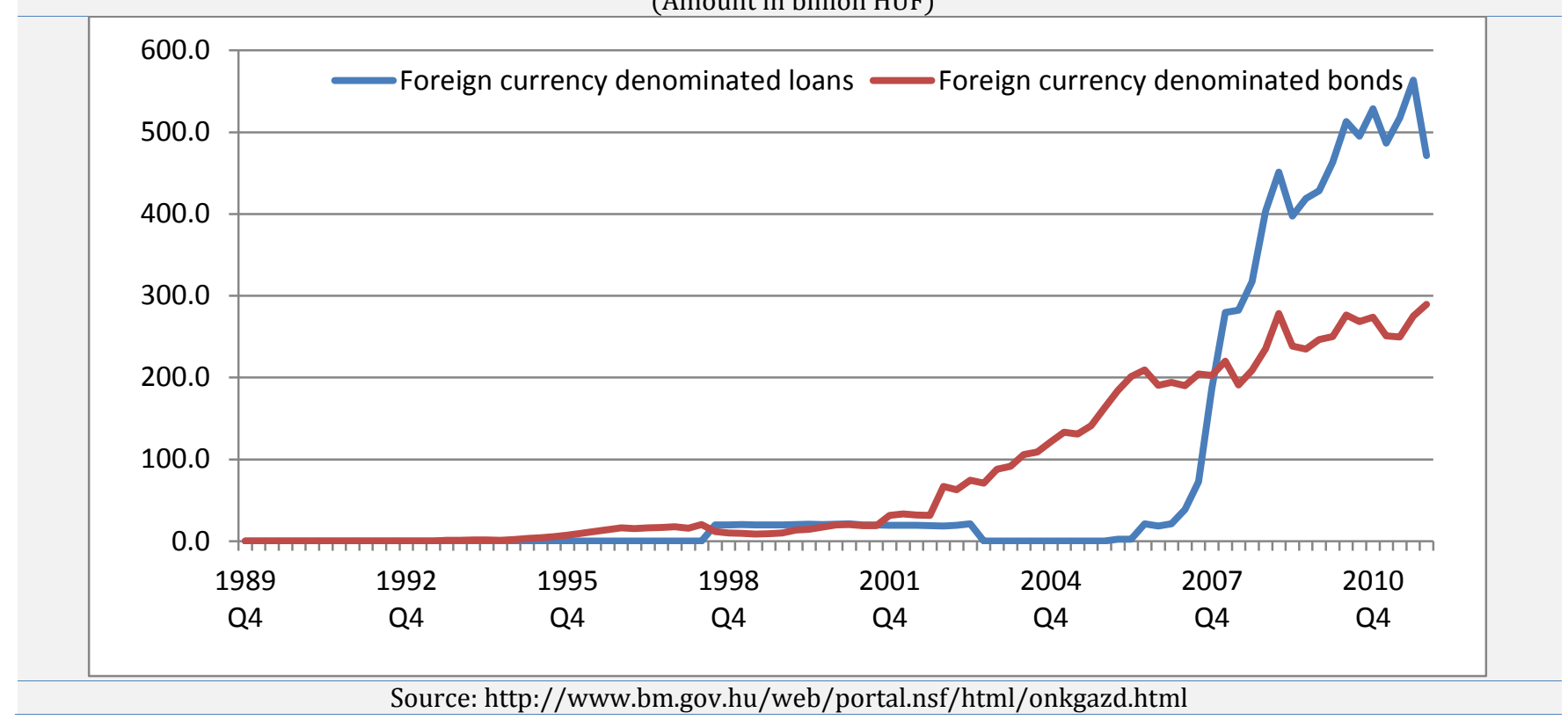

\subsection{Systemic risks of borrowing of Hungarian municipalities}

The economic downturn in 2008 had a strong impact on municipal finance all over the world. In countries in which municipalities depend on property tax revenues, municipalities watched their property tax revenues sink as property prices fell, leading to difficulties in maintaining the level of services. Local governments that depended on more volatile revenue sources that directly depended on the economy, such as sales taxes or income taxes, were even worse off after 2008. In post transition countries, where granting debt-raising power to local levels was an important part of the decentralization process and was often done without regulations that would ensure avoiding over-indebtedness, the problems were even bigger.

Some of the risks associated with local borrowing were born at the time when the rules about Hungarian public administration were laid down. This section summarizes and examines these risks one by one,

\subsection{The risk of unbalanced budgets}

Diminishing state subsidies, as a consequence of the hard budget constraint of the central budget, would not be a problem if municipalities were able to raise revenues on their own. The absorption capacity of Hungarian municipalities, however - especially after the economic downturn in 2008 - is very low. The debt payments of municipalities were also considerably higher than they had been before 2008, which can be explained in part by the change in the value of Hungarian Forint relative to the Euro and the Swiss Franc. Since the expenditures of municipalities are increasing and other revenue sources are shrinking, the risk of budget deficits is significant.

\subsection{Lack of public accountability and access to information}

Hegedüs and Tönkö (2006) have documented that since 2000, many municipalities in Hungary have used publicprivate partnerships to create infrastructure, so that the costs of the investment were deferred. It is thus difficult to assess the real indebtedness of a municipality at any given date. Furthermore, due to the lack of regulation, future debt service does not have to be calculated ahead of time, so municipal decision makers have avoided appearing responsible for future indebtedness.

The main purpose of the public-private partnerships was to avoid direct municipal borrowing and to lengthen the financing period of the investment. In these cases, private borrowing is backed by municipal guarantees. After a certain period, the municipality assumes ownership of the assets. If the municipality has to repay the loan instead of a private company, the responsibility is further deferred.

\subsection{Moral hazard and the risk of over-indebtedness of the sector}

Moral hazard in the practice of Hungarian municipal borrowing is very high and deserves special attention. The indebtedness of the municipal sector increased 1260\% from 2001 to 2007. In 2007, according to Homolya and 
Szigel (2008), about 83 percent of municipal borrowing was not backed by any revenue stream or immobile assets. When a bank officer was asked why the bank had offered a Swiss franc-based loan to an obviously not creditworthy small municipality, the officer replied: "If we do not do it, another bank will." This behavior increases the risk of over-indebtedness of the sector and makes one doubt whether municipalities were aware at all of the risks associated with foreign currency borrowing.

In 2007, municipalities borrowed substantially more than in previous years. This boom had several reasons. Some municipalities borrowed while they still could, since tightening the borrowing regulation had been on the government's agenda for years. Others raised loans in foreign currencies with a speculative purpose, because the interest rates made the loans appear to be a good investment. Homolya and Szigel (2008) also observed that the borrowed money then ended up in Forint-based deposit accounts. The foreign currency debts were not hedged.

According to the results of the research of Barati-Stec and Hogye (2012) municipal decision makers often assumed that the central government would bail out insolvent municipalities. Furthermore, local officials often lacked basic financial knowledge about borrowing. For example, they were unfamiliar with the risks associated with foreign currency loans and could rarely afford to hire budgeting, planning, infrastructure, or finance advisors to guide them.

\subsection{Carrying out unnecessary and costly investments}

The targeted grants set priorities for municipalities from the higher levels and distort local preferences. Underfinanced local governments seek all possible revenues that they can raise and are likely to apply for grants for investments they do not need if that is the only way to get access to government funding and at the same time, the long-term maintenance cost of the investment is not taken into consideration. As a result of centralized financing, local decision makers are not publicly accountable for their actions and in some cases informing the public before making an investment means only a short announcement in the local paper. Although they are obliged to do so by law, they do not organize public hearings to discuss major investments as Barati-Stec and Hogye (2012) found during their research.

\subsection{Unhealthy financing mechanisms}

Since municipalities can issue bonds for a "general purpose," it is also possible that some of these bond issues are needed to cover operating expenses. According to Homolya and Szigel (2008) only 50 percent of bond issues had a direct investment purpose, 10 percent were explicitly for financing operating expenses, and 40 percent were "general-purpose" bonds. Although "general purpose" means that the use of the bonds was not clarified at the time of the issue, so they could have been spent on investments or operating costs, it is likely that 50 percent of total bond issues were used to cover current expenses.

As loans and bond issues are made in subsequent years, each one with a different grace period set in a negotiation process between the lender and the municipality, the municipality may have to start repaying all the loans at once. This, besides indicating incompetence on the municipality's side also raises questions about the incentives of the banks in these situations. There are between 10 and 15 financial institutions in the Hungarian local credit market, making it very competitive. Even though municipalities' creditworthiness is low, the financial sector is willing to take the risks associated with local borrowing. Moreover, the market is not particularly transparent, so the banks find it difficult to estimate the creditworthiness of a municipal borrower.

Municipalities sell land and buildings through off-budget institutions, which makes it hard to trace how the revenue from these transactions is used. This practice further decreases transparency and suggests that capital income is being used to cover operating expenditures.

\subsection{Changes in regulation \& finance of Hungarian municipalities after the economic downturn}

Since the spending of the municipal sector represents almost 14 percent of Hungarian GDP, municipal finance imbalances will have a significant effect at the macroeconomic level. Having high subnational spending in relation to the GDP is a characteristic of the northern countries (the proportions for Norway and Denmark are 32.9 and 13.1 percent of GDP, respectively). Decentralized spending is also a characteristic of some of the former Communist countries; in the Czech Republic the proportion is 11.9 percent and in Ukraine it is 12.6 percent of GDP (Slack 2009: Table 5). However, Escolano et al. (2012) concluded that the positive effect of decentralized expenditures is reduced if local governments depend largely on central transfers at the same time - another characteristic of former communist countries.

After 2008, Hungarian municipalities, as well as the central government, found themselves in a difficult economic situation. Markets were shrinking and the state sovereign rating in November 7, 2008, was changed to A3 from A2 
by Moody's. On March 1, 2009, it was downgraded to Baa1. S\&P changed the rating on the November 17, 2008, from BBB+ to BBB and, in March 2009, to BBB-. Some companies that had provided the largest tax base for local governments closed down and the number of unemployed increased rapidly, placing an extra burden on municipal budgets. The state cut back subsidies to the local sector for stabilization purposes by 6 percent in 2009 (from 66.6 billion to 62.4 billion Hungarian Forints). Another 70 billion Forints for raising public servants' wages were also taken away from the public sector. The Hungarian government that was elected in 2010 and re-elected in 2014 introduced a series of reforms concerning all levels of public administration and their finances.

\subsection{Constitutional changes}

The new Constitution took effect on January 1, 2012. When the old Constitution was no longer in force, many regulations that were included in it that affected municipalities also became nullified while new laws to regulate municipalities had not yet been created. The old Constitution included a paragraph about municipal associations, stating that forming associations is a free decision of the member municipalities and higher levels of government cannot force municipalities to carry out tasks together. The new Constitution, however, vaguely states that other sectoral laws can oblige municipalities to cooperate while carrying out tasks. Also, the new Constitution does not comply with the requirement of the European Charter of Local Self-Governments, which states that municipal rights should be protected by the country's Constitution. This provision was also criticized by the Venice Commission. ${ }^{33}$

\subsection{Structural changes and reallocation of tasks}

The creation of a new formal level of micro-regions that would replace free associations of municipalities has been among the government's plans for more than 10 years. This step shifts some of the more expensive tasks to this level from the local level. In-depth interviews with municipal representatives in 2010 by researchers at Corvinus University suggest that municipalities generally did not oppose a new formal level between them and the counties. The services that municipalities would have preferred to "upload" to the micro-regional level were education, health care, solid waste, and sewage collection and treatment. As a final decision of the government the education became centralized - so instead of stepping one level up, it skipped and went directly to the center - and now it is under one single national authority, even though municipalities strongly opposed to the state taking over this service $^{34}$. While other infrastructural services remained local services the new level still mainly only fulfils administrative tasks (issuing ID cards, passports). Numerous services - like mid and higher level education, health care - that had been provided by counties also got uploaded to the central level, making the role of the counties in public administration even lighter if possible.

\subsection{Local finance}

Instead of the normative grants - discussed before - a new form of operational subsidy was introduced that took into consideration the total tax capacity of the municipality. The subsidy is calculated based on the difference between the sum of the maximum possible per capita PIT and business turnover tax (tax potential) of the municipality and an amount assigned by the government based on the size of the municipality (the bigger the municipality the higher this amount is). If the tax potential is lower than the amount assigned by the government, the normative grant will make up for the difference, if the potential is more than the normative amount, than the grant will be reduced by the amount of the difference.

The number of municipalities declaring insolvency between 1996 and 2007 was 22. Since 2009, however, there have been 23 new cases. Although the insolvent municipalities during the first 10 years were mainly small settlements, the recent cases involved larger municipalities as well. The government set new regulation on local borrowing (Act CXCIV (2011) on Economic Stability) as well. Under the new act, municipalities can only borrow short term without direct permission but decisions about loans for investments - with some exemptions ${ }^{35}$ - will be made on a case-by-case basis at the central level. Debt can only be taken on if the debt service in any year will be under $50 \%$ of the own source municipal revenues, forcing decision makers to take into consideration the different grace periods of borrowing in subsequent years.

\subsection{Sector-wide bailout}

\footnotetext{
33. The European Commission for Democracy through Law (the Venice Commission) was established in 1990 for dealing with emergency issues in constitutional matters.

34. Municipalities are so desperate to maintain this control that some have even re-classified school buildings as residential rental units, so that the state cannot take them over.

${ }^{35}$ According to the Act CXCIV of 2011 on the economic stability of Hungary (article 10/2), there is no need for approval for (i) liquidity loans, (ii) for providing the own part of already approved EU or other international financed project, (iii) reorganization loans and (iv) in case of investmnet loans up to 100.000.000 HUF for Budapest and other cities with county rights, 20.000.000 HUF for national minority self governments and in all other cases $20 \%$ of own revenues, but maximum 10.000.000 HUF.
} 
The central government and county-level representatives signed an agreement in October 2011 about the bailout of the counties' debt and taking over county tasks and assets. Before the details of this transaction were discussed, municipal associations were noting that the county assets are worth more than the amount of debts, so bailouts would not be needed. After a lengthy negotiation period, the counties signed the agreement according to which the state took over all of the assets of and the tasks performed by these institutions leaving the counties even more weightless. In 2012 a new announcement came about the partial bailout of the municipal sector and was followed by decisions resulting in the total bailout by March 2014, just 4 weeks before the new elections.

In case of smaller settlements the main reason for the very high level of indebtedness was the asymmetrical financing system and lack of fiscal capacities - as described before in this paper - , matched with the undifferentiated obligatory service provision (vertical fiscal imbalance). Bigger municipalities were better off financially, but started investments that were beyond their limits. In 2012, the government announced taking over the entire debt burden of municipalities with less than 5000 inhabitants (more than half of Hungarian municipalities fall in this category). Later, 14 municipalities were taken out from the first round of consolidation, as the per capita debt was higher than 200.000 HUF (1000 USD) and the government started a special investigation to reveal the reasons behind this relatively high per capita debt. ${ }^{36}$ In case of municipalities with more than 5000 inhabitants, $40-70 \%$ of the total debt was going to be taken over by the state with the exact amounts to be determined in case by case negotiations. Even though the government elaborated a formula for calculating these amounts in each settlement, the practice suggested that decisions were made on an ad hoc basis again, giving ground to rumors about political influence. In March 2014, despite the negative critics, the central government took all municipal debt regardless their causes, size and financial situation of the indebted municipality ${ }^{37}$.

\subsection{Conclusions: reforms based on Hungarian tradition and international examples}

We can conclude that the municipal level wished for reforms leading to greater fiscal decentralization, more local autonomy, and increased transparency. The government elected in 2010 had the chance of completing the decentralization process that started 20 years ago, but instead, has used the situation in 2008 to start a massive recentralization process.

Given that the main problem of Hungarian local finances was the inability of small settlements, a vast majority of the sector, to finance their operations, and as a consequence, their over indebtedness due to the constant rollover of liquid loans, it is questionable whether the new regulations discussed in the previous section are going to meet their expectations.

The negotiations about the debt between the state and the banking sector are still going on. There is little doubt about the need for re-regulating small settlements' service obligation and financing practices, however, the new rules just shift some of the tasks and revenues away while making long term borrowing stricter, without easing normal, everyday service provision and operation in these settlements. The new laws do not address the difficulties of small local governments since they will have to continue to borrow short term, taking out liquidity loans, reproducing the old problems. The author's suggestions based on the findings of recent literature on decentralization, after evaluating the reform steps of the current government are as follows:

1. The current bailout sends the message that the central government is ready to 'save' the insolvent municipalities and sets a bad example for the fiscally prudent ones. This practice favours the fiscally imprudent and should be given up.

2. Differentiation among different-sized governments is needed when regulating subnational borrowing practices to ease normal, everyday service provision and operation of small settlements.

3. The right of larger municipalities ${ }^{38}$ to introduce special taxes should also be examined. Special rights could be given to cities that are or could be the centre of economic development in their region. This reform could be introduced gradually. First, the city of Budapest could be given this special right (about one-fifth of Hungary's population lives in the capital), then, based on the lessons learnt, the group of special-tax cities could be broadened to the five to seven largest Hungarian cities. 39

The decentralization process follows a different path in each country and change does not occur all at once. Hungary has a historical heritage that made it difficult to introduce the amalgamation of municipalities to provide services or

\footnotetext{
${ }^{36}$ A revealing fact about the whole process and indication of that the effects of the bailouts were not examined thoroughly, is that the government learnt about these 14 cases only after the total bailout of the sector was already announced.

37 When the value of the Hungarian Forint relative to the EURO and the Swiss Franc, the currencies in which most households' debt was denominated, fell, the government accepted a law on the of these debts at a centrally given rate, which in case of the EURO was 250 , and for the Swiss Frank 180 . The market rates at that time were 295 and 236 respectively. The first idea of doing the same thing in case of public debt came from one of the Ministers of State for the Prime Minister's Office and mayor of Hódmezóvásárhely, a town seriously indebted in Swiss Frank.

38. About 50 percent of Hungarian local debt is raised by 30 municipalities, out of a total of 3200 municipalities.

39. The largest Hungarian cities are Budapest (pop. 2.000.000) Debrecen (206.225), Miskolc (170,234), Szeged (169,678), Pecs (156,974), Gyor (130476), Nyiregyhaza $(117,597)$.
} 
delegating revenue-raising power to the micro-regional level. However, over time, Hungary could learn from the practices and examples of mature democracies to broaden municipal rights rather than curtailing them, provided that the necessary financial safeguards are in place.

\section{References}

Barati-Stec, Izabella and Mihaly Hogye, 2012. Önkormányzatok költségvetéskészítési gyakorlata (Budgeting Technics of Municipalities. Pro Publico Bono Online. ISSN 2062-9966 (online)

Boadway, Robin and Anwar Shah, 2009. Fiscal federalism: Principles and practice of multi-level governance. New York: Cambridge University Press.

Boadway, Robin, and Harry Kitchen, 1999. Canadian tax policy. Third Edition. Toronto: Canadian Tax Foundation.

Chatrie, Isabelle, 2009. Economic outlook: Sub-national public finance in the European Union. Dexia Crédit Local, presentation made in Brighton, December 11.

Ebel, Robert and Robert Taliercio, 2005. Subnational tax policy design and administration. Tax Notes International: 919-936

Escolano, Julio, Luc Eyraud, Marialuz Moreno Badia, Juliane Sarnes, and Anita Tuladhar, 2012. Fiscal performance, institutional design and decentralization in European Union countries. IMF Working Paper. WP/12/45. Washington, D.C.: International Monetary Fund: 1-32.

Gál, Erzsébet, 2012. Az önkormányzati adó- és követelésminősítésének elmélet és gyakorlati problémái. (Theoretical and Practical Challenges of Municipal Credit Rating). Ph.D. Dissertation. Miskolc University.

Gillette, Clayton P., Political Will and Fiscal Federalism in Municipal Bankruptcy (March 23, 2011). NYU School of Law, Public Law Research Paper No. 11-22; NYU Law and Economics Research Paper No. 11-13: 1-54. Available at SSRN: http://ssrn.com/abstract=1793173 or http://dx.doi.org/10.2139/ssrn.1793173

Hegedüs, J. and Tönkö, A., 2006. Az önkormányzati gazdasági társaságok szerepe a helyi önkormányzatok vagyongazdálkodásában: feltételes kötelezettségvállalás problémája. (The “contingent liability" problem.) Budapest: Városkutatás Kft.: 1-17

Homolya, Dániel and Gábor Szigel, 2008. Lending to local governments: Risks and behaviour of Hungarian banks. Hungarian National Bank Bulletin 3(2): 20-29.

Hooghe Liesbet and Marks, Gary, 2001. Types of multi level governance, Department of Political Science, University of North Carolina:1-32.

Krugman, Paul, 2011. Depression and democracy. New York Times, New York Edition, December 12, page A23.

Liu, Lili, and Steven B. Webb, 2011. Laws for fiscal responsibility for sub-national discipline: International Experience. WPS5587. Washington, D.C.: World Bank, 1-56.

Paulais, Thierry. 2009. Local governments and the financial crisis: An analysis. Washington, D.C.: The Cities Alliance, $1-26$.

Scheppele, Kim Lane, 2011. Hungary's constitutional revolution. The New York Times, Opinion Pages. 19th December.

Slack, Enid, 2009. Guide to municipal finance. Nairobi: UN-HABITAT, 1-90.

Swianiewicz, Pawel, 2010. If territorial fragmentation is a problem, is amalgamation a solution? An East European Perspective. Local Government Studies. 36(02):183-203.

Szalai, Akos, and Almos Tassonyi, 2004. Value-based property taxation: options for Hungary. Environment and Planning C: Government and Policy 22(4): 475-632. 